\title{
Nitrogen Metabolism at Tillering Stage Differently Affects the Grain Yield and Grain Protein Content in Two Durum Wheat Cultivars
}

\author{
Stefania Fortunato ${ }^{1,+}{ }^{+}$Domenica Nigro ${ }^{1,+}{ }^{,}$Annalisa Paradiso ${ }^{2}$, Giovanna Cucci ${ }^{3}$, \\ Giovanni Lacolla ${ }^{3}$, Roberta Trani ${ }^{2}{ }^{\mathbb{D}}$, Gennaro Agrimi ${ }^{4}{ }^{\mathbb{D}}$, Antonio Blanco ${ }^{1}$, \\ Maria Concetta de Pinto ${ }^{2, *}$ and Agata Gadaleta ${ }^{3, *}$ \\ 1 Department of Soil, Plant and Food Sciences, University of Bari “Aldo Moro”, Via Amendola 165/a, \\ 70126 Bari, Italy; stefania.fortunato26@gmail.com (S.F.); domenica.nigro@uniba.it (D.N.); \\ antonio.blanco@uniba.it (A.B.) \\ 2 Department of Biology, University of Bari "Aldo Moro", Via Orabona 4, 70126 Bari, Italy; \\ annalisa.paradiso@uniba.it (A.P.); roby.trani@libero.it (R.T.) \\ 3 Department of Agricultural and Environmental Sciences, University of Bari "Aldo Moro", Via Amendola \\ 165/a, 70126 Bari, Italy; giovanna.cucci@uniba.it (G.C.); giovanni.lacolla@uniba.it (G.L.) \\ 4 Department of Biosciences, Biotechnologies and Biopharmaceutics, University of Bari "Aldo Moro", Via \\ Orabona 4, 70126 Bari, Italy; gennaro.agrimi@uniba.it \\ * Correspondence: mariaconcetta.depinto@uniba.it (M.C.d.P.); agata.gadaleta@uniba.it (A.G.) \\ + These authors equally contributed to the work.
}

Received: 22 July 2019; Accepted: 28 September 2019; Published: 1 October 2019

\begin{abstract}
Soil nitrogen abundance, as well as nitrogen use efficiency (NUE), significantly affect the crop yield and grain protein content (GPC). Depending on the genotype, a negative correlation between the yield and GPC can occur. The aim of the study was to assess the agronomic performance, and to explore physiological pathways for the efficient use of $\mathrm{N}$ fertilizer for two durum wheat cultivars, "Aureo" and "Vespucci". After fertilization, the nitrogen content and values of some of the agronomic parameters and yield-related traits increased in both cultivars; nevertheless, a simultaneous rise in both the yield and GPC occurred only in Aureo. The biochemical parameters, analyzed at tillering, confirm the genotypic specificity of nitrogen use. In Vespucci's roots, the nitrogen supply did not affect the nitrate reductase (NR), but greatly increased the amino acids and proteins, suggesting that ammonium is preferentially assimilated. In Aureo, nitrate is in part assimilated by the roots, as suggested by the ammonium increase and NR enhancement. In the leaves of both cultivars, organic nitrogen significantly increased after fertilization; however, the rise in amino acids, as well as in NR activity, was higher in Aureo than in Vespucci. These results indicate that the different nitrogen use, and in particular the diverse NR behavior, at tillering, are in part responsible of the cultivar differences in grain yield and GPC.
\end{abstract}

Keywords: durum wheat; grain protein content; grain yield; nitrogen metabolism; nitrogen use efficiency

\section{Introduction}

Nitrogen is an essential element playing a crucial role in plant growth and development, as it is involved in the biosynthesis of several molecules, such as amino acids, proteins, nucleotides, nucleic acids, chlorophyll, vitamins, and hormones [1,2]. Thus, considering its importance as a limiting factor, its abundance in the soil significantly affects both crops' quality and yield [3]. Durum wheat (Triticum turgidum var. durum Desf.) represents about $5 \%$ of the total global wheat production, with Italy being 
the major producer, with an average of almost 4.0 MMT in the 2015-2016 cropping season (International Grain Council, https://www.igc.int/en/default.aspx).

The economic value of this crop depends on several agronomic traits, such as grain yield and grain protein content (GPC), the latter being directly related to both the nutritional and technological values of the final products $[4,5]$. As reported by several authors, both traits are strictly affected by nitrogen metabolism during plant growth [6,7]. Indeed, a stable QTL (Quantitative Trait Locus) for GPC and grain protein deviation (GPD) were found to be co-migrating with nitrogen-related genes [8]. As typical quantitative traits, their expression is regulated by a complex genetic system, and is affected by environmental factors, as well as genotype and management practices [9]. Breeding programs aimed at the constitution of more efficient varieties, and genetic studies on the identification of the key elements involved in nutrient utilization will surely benefit from the recent release of the durum wheat genome assembly, a tool of great importance for studying durum wheat breeding and gene function, as well as QTL analysis for relevant agronomic traits [10]. Currently, to solve issues of soil N shortage and to increase crop yields and GPC, mineral $\mathrm{N}$ fertilizers are worldwide extensively used in intensive farming practices [11]. However, depending on the species and cultivar, only $30-50 \%$ of the $\mathrm{N}$ supplied to the soil is absorbed by the plants, and the remaining part is lost into the environment by leaching, denitrification, and volatilization [12].

To prevent these issues and improve $\mathrm{N}$ utilization, some agronomical strategies have been developed, such as late and split nitrogen applications, which improved the GPC [13-15]. The understanding of how plants respond to and use the available $\mathrm{N}$ in the soil has attracted considerable interest from the scientific community [16]. Plant nitrogen-use efficiency (NUE) depends on different steps that consider not only $\mathrm{N}$ uptake, but also $\mathrm{N}$ assimilation and remobilization [1]. In wheat, as well as in many other crops, NUE is a genotype-dependent response [17-19].

To date, few attempts have focused on defining nitrogen fertilizer efficiency in durum wheat [20,21]. $\mathrm{N}$ can be absorbed and utilized by plants, from both organic and inorganic sources, but generally, nitrate and ammonium are the most commonly used forms, as they are more available and more easily converted in organic compounds [3]. Thus, NUE is directly linked to nitrate and ammonium assimilatory pathways. Nitrate absorbed from the soil can be stored or assimilated in the roots, or transported via xylem to the shoot. Depending on the nitrate concentration in the soil, environmental conditions, and genotypes, nitrate assimilation can occur in the roots or shoots [22]. In order to be assimilated, nitrate has to be firstly reduced to ammonium, in a two-step reaction. In the first step, occurring in the cytosol, nitrate reductase (NR) reduces nitrate to nitrite; nitrite is then further reduced to ammonium by nitrite reductase (NiR) localized in plastids $[23,24]$.

In cereals, the NR activity has been correlated with the grain yield and GPC, and used as a marker to estimate the $\mathrm{N}$ status of the plant [25-28].

Ammonium, taken directly from the soil or derived from nitrate reduction, is assimilated into amino acids through the activity of glutamine synthetase (GS) and glutamate synthase (GOGAT), which work synergistically [29]. GS and GOGAT are highly responsive to N supply [30,31]. GS catalyzes the amidation of the $\gamma$-carboxyl group of glutamate to form glutamine. GOGAT transfers ammonium from glutamine to 2-oxoglutarate to form two glutamate molecules [32]. In plants, two different isoforms of GOGAT exist, namely: ferredoxin (Fd)-dependent and NADH-dependent, which are active in photosynthesizing and non-photosynthesizing cells, respectively [33,34]. Both GOGAT genes have found to be associated with GPC in durum wheat $[35,36]$. Furthermore, GS has been proposed as a candidate gene for improving NUE by several authors, and its relationship with GPC has also been widely reported [37-41].

The aim of the present work was to study if and how inorganic $\mathrm{N}$ fertilization could affect the grain yield and GPC of two durum wheat genotypes, Aureo and Vespucci, which were chosen because they are the genotypes that exhibit an elevated yield and GPC [42,43]. Also, in the present study, we wanted to assess the $\mathrm{N}$ fertilization effects on the above-mentioned agronomic traits for these two durum wheat genotypes, and to explore whether the different improvements in the yield and GPC 
observed in the two genotypes after $\mathrm{N}$ fertilization could depend on differences in the $\mathrm{N}$ metabolism in the roots and leaves at the tillering stage.

\section{Materials and Methods}

\subsection{Plant Material and Field Experiment Design}

Two durum wheat cultivars, Aureo and Vespucci, parents of a segregant recombinant inbred lines (RIL) population, were chosen from a wider collection of 39 tetraploid genotypes included in the "National Trials", carried out in South-Italy in the 2014-2015 and 2015-2016 growing seasons, evaluated for both quality and yield related traits [42,43]. Based on the data collected in these trials, the aforementioned two cultivars were chosen, showing a similar value of grain yield components and GPC, in order to study whether inorganic $\mathrm{N}$ fertilization could affect the two traits.

The experimentation was carried out in the 2016-2017 growing season in open air, in containers of $0.72 \mathrm{~m} \varnothing$ and $0.60 \mathrm{~m}$ high, filled with $293 \mathrm{~kg}$ of clayey-silty granulometry, composed of the following: $58 \%$ total sand, $21.5 \%$ silt, and $20.5 \%$ clay. Details about the particle size, chemical properties, and hydrologic properties of the soil used in the trial are reported in the Table S1.

The characterization of the soil was performed using the official methodologies [44]. Plants were sowed in November, with a sowing rate of 350 seeds $\mathrm{m}^{-2}$. Total rainfall during the growing season was $451 \mathrm{~mm}$. A detailed thermo-pluviometric trend is reported in Supplementary Figure S1. The two genotypes were grown in a complete randomized block design with three replications for both the control and fertilized plants. The plants were supplied with mineral fertilizer and compared with a control test grown without fertilizer. We used $120 \mathrm{U} /$ ha of ammonium nitrate (1:1 ratio) as the mineral fertilizer; $30 \%$ of which was supplied during the seedling stage (stage 12 in the Zadoks scale; hereafter indicated as N36), and the remaining 70\% during the flowering stage (stage 61 in the Zadoks scale; hereafter indicated as N120). At the tillering stage (stage 24 in the Zadoks scale), the roots and leaves were collected from the control and fertilized plants, frozen in liquid nitrogen, and stored at $-80^{\circ} \mathrm{C}$. The sampling, made by pooling five different plants for each container in triplicate, was carried out in the morning, between 09:00 and 11:00.

\subsection{Agronomic, Productive, and Qualitative Parameters}

The chlorophyll content per leaf area was measured with a Minolta SPAD 502 Chlorophyll Meter (Minolta, Osaka, Japan) on a flag leaf at the booting and flowering stages. The pants were harvested at maturity, and both the agronomic- and yield-related traits were evaluated. Specifically, the aerial biomass, plant height, number of culms, and number of spikes were retrieved, along with a thousand kernels' weight, hectolitre weight, grain weight, and grain yield data [45].

The grain protein content (GPC) was assessed on $3 \mathrm{~g}$ of whole meal flour using a dual beam near infrared reflectance spectrophotometer (Zeutec Spectra Alyzer Premium, ZeutecBüchi, Rendsburg, Germany).

\subsection{Intracellular Inorganic and Organic Nitrogen Pools}

To determine the inorganic $\mathrm{N}$ and free amino acids, the plant roots and leaves collected in the tillering stage were kept frozen in liquid nitrogen, and were ground in a mortar with 1:10 $(w / v) \mathrm{H}_{2} \mathrm{Od}$. Polyvinylpyrrolidone (PVP; $0.01 \mathrm{~g} \mathrm{~mL}^{-1}$ ) was added to the crude extracts, which were incubated for $1 \mathrm{~h}$ at room temperature. After the incubation, the extracts were centrifuged at $16,000 \times g$ for $15 \mathrm{~min}$ at $4{ }^{\circ} \mathrm{C}$, and supernatants collected for the analyses.

For the ammonium determination, $50 \mu \mathrm{L}$ of supernatant was added to $550 \mu \mathrm{L} \mathrm{H}_{2} \mathrm{Od}$ and $25 \mu \mathrm{L}$ Nessler's reagent (Sigma-Aldrich $®$, Saint Louis, Missouri, USA). The samples were incubated for $15 \mathrm{~min}$ at room temperature, and the ammonium concentration was measured by UV-VIS spectrophotometry at $\mathrm{A} 420 \mathrm{~nm}$. The results were expressed as $\mu \mathrm{g} \mathrm{g}^{-1} \mathrm{FW}$. 
The nitrate and nitrite contents were measured with the Griess method according to Verdon et al. [46]. In this method, the nitrate was reduced to nitrite by nitrate reductase with a low concentration of NADPH, in order to avoid the interference of $\mathrm{NADP}^{+}$with the Griess reaction. This reaction was coupled with a glucose-6-phosphate dehydrogenase reaction to ensure a continued reduction of NADPH.

The content of the free amino acids was determined with the ninhydrin method, as described by Magné and Larher [47]. Briefly, $200 \mu \mathrm{L}$ of leaf or root extracts were incubated with $100 \mu \mathrm{L}$ of $0.2 \mathrm{M}$ sodium citrate buffer ( $\mathrm{pH} 4.6$ ), and $200 \mu \mathrm{L}$ of $1 \%$ ninhydrin and $0.03 \%$ ascorbate solution. After $15 \mathrm{~min}$ of incubation at $100{ }^{\circ} \mathrm{C}$, the reaction was stopped in ice, and $600 \mu \mathrm{L}$ of $60 \%$ ethanol was added. The absorbance was read at $570 \mathrm{~nm}$ in a Beckmann DU 6400 spectrophotometers (Beckmann Coulter, Brea, California, USA). The amino acid content was expressed as $\mu$ moles $\mathrm{g}^{-1} \mathrm{FW}$.

The soluble proteins were assayed according to Bradford [48], using bovine albumin as a standard.

For the determination of the photosynthetic pigments, the leaves were frozen in liquid nitrogen and ground in a mortar with 1:30 (w/v) $80 \%$ acetone. The crude extracts were centrifuged at $10,000 \times g$ for $20 \mathrm{~min}$ at $4{ }^{\circ} \mathrm{C}$. The supernatants were used to determine the absorbance at $663.2,648.8$, and $470 \mathrm{~nm}$, by visible spectrophotometry. The content of the total chlorophylls was calculated as described by Zhang and Kirkham [49].

\subsection{Enzymatic Activities Assay}

Roots and leaves, kept in liquid N, were ground in a mortar with 1:5 (w/v) extraction buffer (50 mM potassium phosphate buffer $\mathrm{pH}$ 7,5; $1 \mathrm{mM}$ EDTA (Ethylenediamine tetraacetic acid); $1 \mathrm{mM}$ DTT (Dithiothreitol); 0,1 mM PMSF (phenylmethylsulfonyl fluoride); $0.1 \mathrm{~g} / \mathrm{L}$ PVP (Polyvinylpyrrolidone)). The crude extracts were centrifuged at $20,000 \times \mathrm{g}$ for $15 \mathrm{~min}$ at $4{ }^{\circ} \mathrm{C}$, and the supernatants used for the determination of the enzymatic activities.

The maximal activity of NR (EC 1.7.1.1) was substantially detected, as described by Gibon et al. [50]. Briefly, one volume of extracts was incubated with five volumes of buffer $(50 \mathrm{mM}$ Hepes/KOH, $\mathrm{pH} 7.5$, $0.04 \%(v / v)$ Triton X-100, $2 \mathrm{mM}$ EDTA, $10 \mu \mathrm{M} \mathrm{Na}_{2} \mathrm{MoO}_{4}, 20 \mu \mathrm{M}$ flavin adenine dinucleotide, $0.5 \mathrm{mM}$ DTT, $20 \mu \mathrm{M}$ leupeptin, $20 \mathrm{mM}$ potassium nitrate). The reaction was started by the addition of $0.6 \mathrm{mM}$ of NADH. After $15 \mathrm{~min}, 300 \mu \mathrm{L}$ aliquots were kept, and the reaction was stopped by adding $25 \mu \mathrm{L}$ of $0.6 \mathrm{mM}$ zinc acetate. Finally, $300 \mu \mathrm{L} 1 \%(w / v)$ sulfanilamide in $3 \mathrm{~N} \mathrm{HCl}$ and $300 \mu \mathrm{L} 0.02 \%(w / v)$ $\mathrm{N}\left(1\right.$-naphtyl)ethylendiamine dihydrochloride in $2.5 \%(v / v) \mathrm{H}_{3} \mathrm{PO}_{4}$ were added. After $20 \mathrm{~min}$, the absorbance was read at $540 \mathrm{~nm}$.

The NiR (EC 1.7.2.2) activity was detected, as described by Takahashi et al. [51]. The GS (EC 6.3.1.2) activity was detected, as described by Nigro et al. [39]. The NADH-GOGAT (EC. 1.4.1.14) and Fd-GOGAT (EC 1.4.7.1) activities were detected, as described by Esposito et al. [52].

\subsection{Statistical Analysis}

The data were analyzed as a randomized design with three biological and five technical replications, and expressed as means \pm SE. Statistical analysis was carried out using Sigma Plot software 12.0 (Systat Software, Inc., San Jose, CA, USA). One-way analysis of variance (ANOVA) and Tukey's comparison test were used to calculate the difference between the two genotypes and the treatments. Differences were considered statistically significant at a $p$-value of $<0.05$.

\section{Results}

\subsection{Effects of Nitrogen Fertilization on Agronomic, Yield, and Qualitative Traits in Two Durum Wheat Cultivars}

The nutritional state of wheat plants was indirectly determined during the booting and flowering stages, through the analysis of the total chlorophyll content obtained by the Soil Plant Analysis Development (SPAD) chlorophyll meter measurements. The Aureo and Vespucci cultivars, grown 
without fertilization (N0), did not show significant a difference in SPAD values in both of the growth stages; $\mathrm{N}$ fertilization (N120) caused a significant increase in the SPAD values, which, however, did not differ among the two cultivars in both the booting and flowering stages (Figure 1).

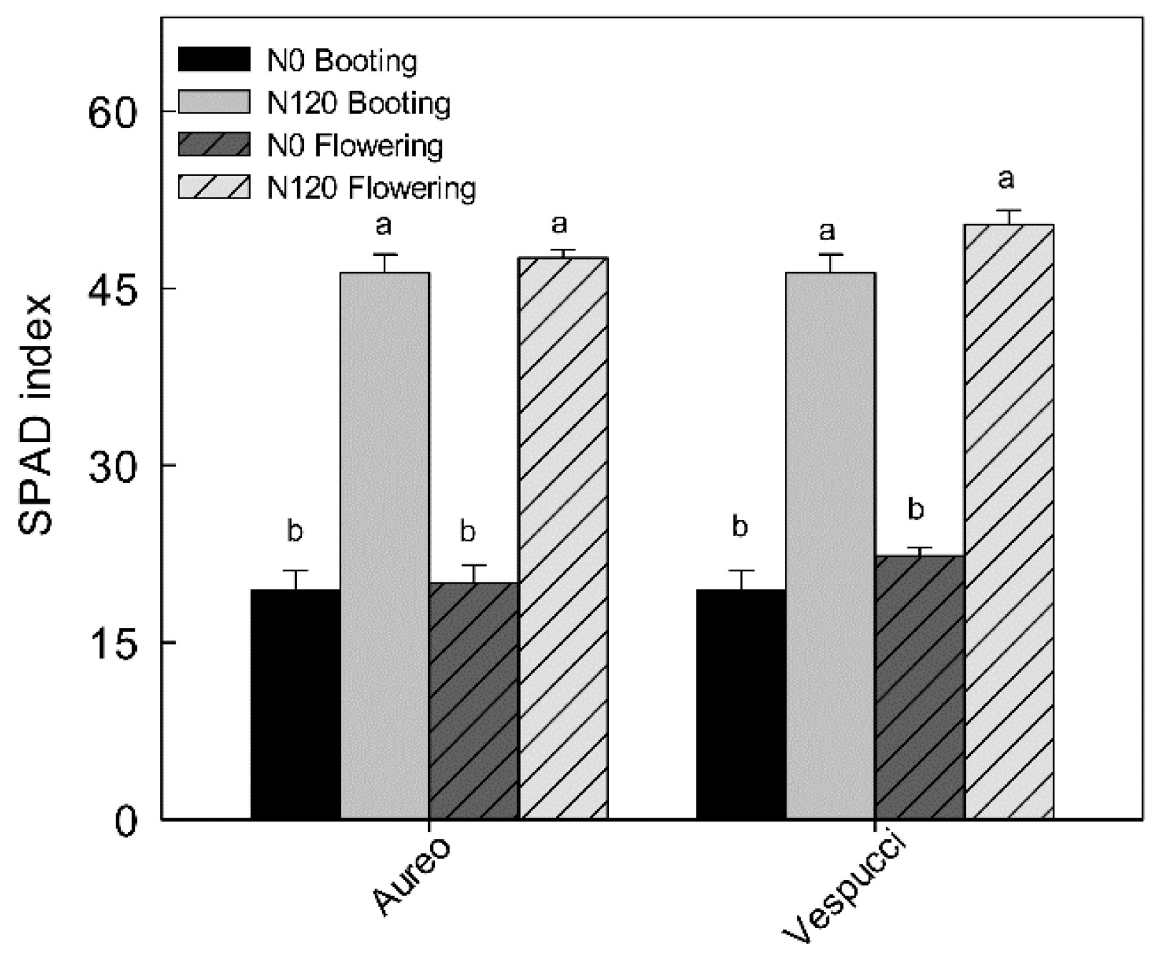

Figure 1. Nitrogen fertilization effect on Soil Plant Analysis Development (SPAD) index during the booting and flowering stages in two durum wheat cultivars. $\mathrm{N} 0=$ control condition without nitrogen supply; $\mathrm{N} 120=120 \mathrm{U} /$ ha of nitrogen fertilization as ammonium nitrate. Data are the means $\pm \mathrm{SE}$ of the traits. Data are the means \pm SE of five experiments; different letters indicate significant differences (one-way ANOVA test; $p<0.05$ ).

To estimate the possible changes in plant growth due to $\mathrm{N}$ treatment, yield-related agronomic traits, such as the aerial biomass, plant height, and number of culms and spikes, were measured at the harvesting time. These traits did not vary significantly among the two genotypes grown under the control conditions (N0). N fertilization (N120) caused an increase in aerial biomass and in the number of culms and spikes of both cultivars; conversely, the plant height in the fertilized plants increased significantly only in Vespucci (Table 1).

Table 1. Influence of nitrogen fertilization on agronomic traits at the harvesting stage. N0 = control condition without nitrogen supply; $120=120 \mathrm{U} /$ ha of nitrogen fertilization. Data are the means of five independent measurements \pm SE. Different letters represent values significantly different $(p \leq 0.05$; Tukey's test).

\begin{tabular}{|c|c|c|c|c|c|}
\hline \multicolumn{2}{|c|}{ Genotypes and Treatment } & $\begin{array}{c}\text { Aerial Biomass } \\
\left(\mathrm{g} / \mathrm{m}^{2}\right)\end{array}$ & $\begin{array}{c}\text { Plant Height } \\
(\mathrm{cm})\end{array}$ & $\begin{array}{c}\text { Number of } \\
\text { Culms }\left(n^{\circ} / m^{2}\right)\end{array}$ & $\begin{array}{c}\text { Number of } \\
\text { Spikes }\left(\mathrm{n}^{\circ} / \mathrm{m}^{2}\right)\end{array}$ \\
\hline \multirow{2}{*}{ Aureo } & N0 & $409^{b} \pm 58$ & $68.3^{\mathrm{b}} \pm 1.7$ & $318.0^{\mathrm{b}} \pm 10$ & $292.4^{\mathrm{b}} \pm 1.8$ \\
\hline & N120 & $1473^{\mathrm{a}} \pm 49$ & $80.7^{\mathrm{a}, \mathrm{b}} \pm 1.7$ & $500.8^{\mathrm{a}} \pm 3.8$ & $465.2^{\mathrm{a}} \pm 3.4$ \\
\hline \multirow{2}{*}{ Vespucci } & N0 & $337^{b} \pm 43$ & $64.3^{\mathrm{b}} \pm 3.4$ & $316.7^{b} \pm 10.3$ & $288.6^{\mathrm{b}} \pm 2.1$ \\
\hline & N120 & $1678^{\mathrm{a}} \pm 44$ & $90.0^{\mathrm{a}} \pm 2.9$ & $482.6^{\mathrm{a}} \pm 14.4$ & $454.5^{\mathrm{a}} \pm 10.9$ \\
\hline
\end{tabular}


The effects of $\mathrm{N}$ fertilization on the thousand kernel weight (TKW), grain yield, and hectolitre weight for the two cultivars are compiled in Table 2. In the absence of fertilization, only the thousand kernels' weight differed among the two cultivars, being higher in Vespucci than in Aureo. Under N fertilization, the three analyzed parameters increased in both of the cultivars, even if the increase in the thousand kernels' weight, and especially in the grain yield, was significantly higher in Vespucci than in Aureo. These data suggest that, at least for the yield, Vespucci was more responsive than Aureo to $\mathrm{N}$ fertilization. On the contrary, GPC, taken into consideration as a qualitative trait, did not differ in the two cultivars grown under the control conditions (N0), and increased significantly under $\mathrm{N}$ fertilization only in Aureo (Table 2).

Table 2. Nitrogen fertilization effects on the yield and quality traits at the harvesting stage. $\mathrm{N} 0=$ control condition without nitrogen supply; N120 $=120 \mathrm{U} /$ ha of nitrogen fertilization. Data are the means of five independent measurements \pm SE. Different letters represent values significantly different $(p \leq 0.05$; Tukey's test).

\begin{tabular}{cccccc}
\hline Cultivars and Treatment & $\begin{array}{c}\text { Thousand Kernels } \\
\text { Weight }(\mathbf{g})\end{array}$ & $\begin{array}{c}\text { Hectolitre } \\
\text { Weight }(\mathbf{g} / \mathbf{h l})\end{array}$ & $\begin{array}{c}\text { Grain Yield } \\
\mathbf{( g / \mathbf { m } ^ { 2 } )}\end{array}$ & $\begin{array}{c}\text { Grain Protein } \\
\text { Content }(\%)\end{array}$ \\
\hline \multirow{2}{*}{ Aureo } & N0 & $43.0^{\mathrm{c}} \pm 1.1$ & $78.3^{\mathrm{b}} \pm 1.3$ & $152^{\mathrm{c}} \pm 26$ & $11.4^{\mathrm{b}} \pm 0.1$ \\
& $\mathrm{~N} 120$ & $45.6^{\mathrm{b}} \pm 1.3$ & $81.3^{\mathrm{a}, \mathrm{b}} \pm 2.3$ & $642^{\mathrm{b}} \pm 38$ & $14.2^{\mathrm{a}} \pm 1.3$ \\
\hline \multirow{2}{*}{ Vespucci } & $\mathrm{N} 0$ & $45.7^{\mathrm{b}} \pm 1.7$ & $79.3^{\mathrm{b}} \pm 2.3$ & $144^{\mathrm{c}} \pm 21$ & $10.8^{\mathrm{b}} \pm 0.2$ \\
& $\mathrm{~N} 120$ & $51.3^{\mathrm{a}} \pm 1.9$ & $83.3^{\mathrm{a}} \pm 2.3$ & $773^{\mathrm{a}} \pm 38$ & $12.1^{\mathrm{b}} \pm 0.3$ \\
\hline
\end{tabular}

\subsection{Nitrogen Metabolism in Two Wheat Cultivars during Tillering Stage}

Considering the positive effects of $\mathrm{N}$ fertilization on some of the parameters of productivity and/or GPC in Vespucci and Aureo, it was verified whether the different improvement in the two cultivars could depend on different changes in the $\mathrm{N}$ metabolism of roots and leaves in the early phases of plant growth (i.e., during the tillering stage).

The intracellular inorganic and organic $\mathrm{N}$ levels in the roots of the two cultivars, grown with or without $\mathrm{N}$ fertilization, were determined (Figure 2).

The content of ammonium ions was significantly different in the two cultivars grown without fertilization, being higher in Vespucci than in Aureo. Notably, the two cultivars responded differently to $\mathrm{N}$ fertilization, as follows: the ammonium ion increased and decreased in the Aureo and Vespucci roots, respectively (Figure 2A). On the other hand, Aureo, without fertilization, showed a higher nitrate content than Vespucci; in both cultivars subjected to $\mathrm{N}$ fertilization, a significant increase in this ion occurred (Figure 2B). The intracellular content of nitrites was not detectable in either the control or under $\mathrm{N}$ fertilization in both of the cultivars (data not shown).

The level of free amino acids and soluble proteins did not significantly differ among the two cultivars grown without fertilization (Figure 2C,D). Under $\mathrm{N}$ treatment, the free amino acids significantly increased in both cultivars, even if the increment was greater in Vespucci than in Aureo (Figure 2C). Similarly, the $\mathrm{N}$ fertilization caused an increase of soluble proteins only in the Vespucci cultivar (Figure 2D). 

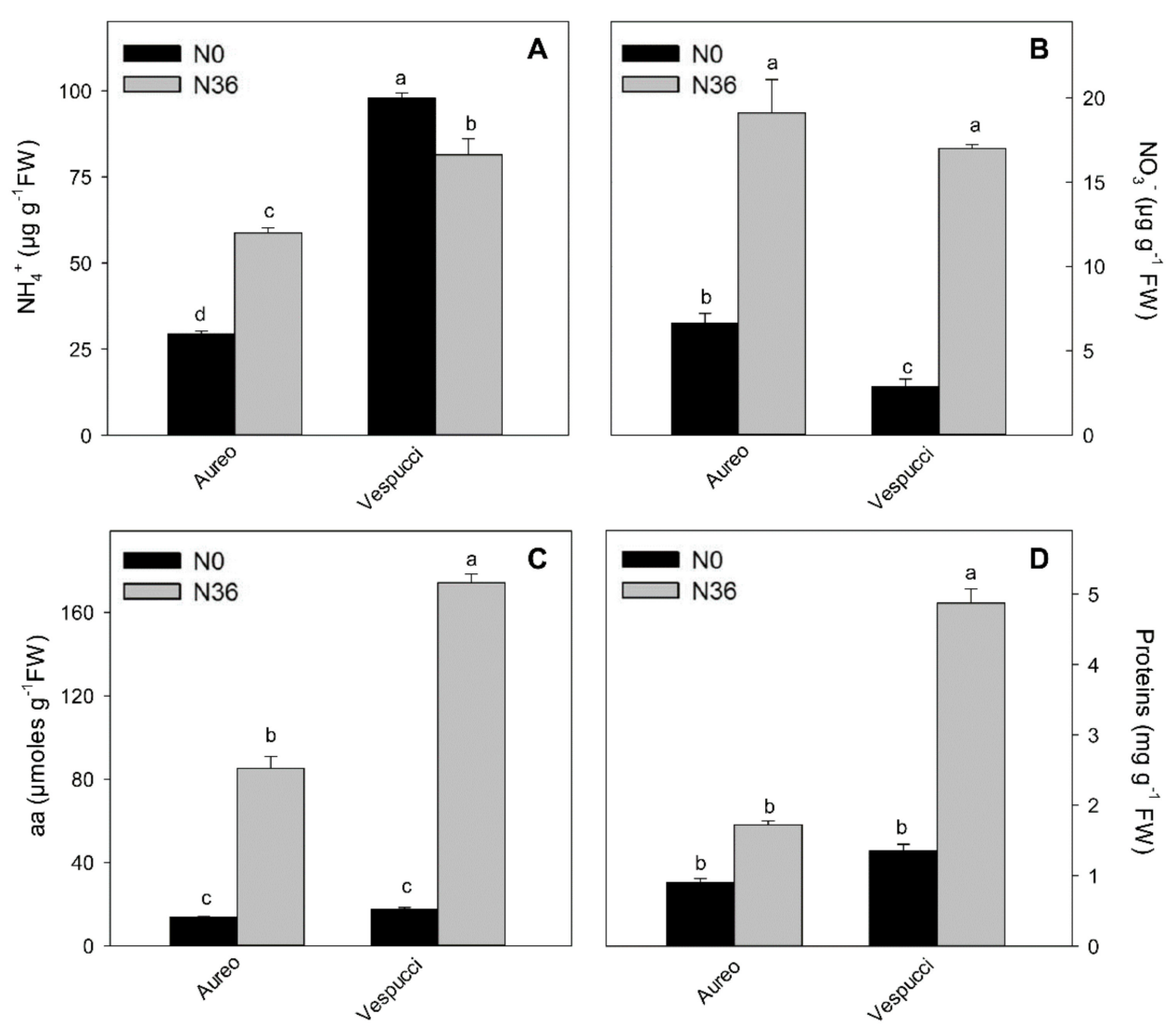

Figure 2. Nitrogen fertilization differently affects the nitrogen content in the roots of two wheat cultivars at the tillering stage. Intracellular content of ammonium (A); nitrate (B); amino acids (C); soluble proteins (D). N0 = control condition without nitrogen supply; N36 = 36 U/ha of nitrogen fertilization as ammonium nitrate. Data are the means \pm SE of five experiments; different letters indicate significant differences (one-way ANOVA test; $p<0.05$ ).

The activity of the enzymes involved in the $\mathrm{N}$ assimilation was also measured in the roots of both cultivars, grown with and without $\mathrm{N}$ fertilization (Figure 3).

The NR and NiR activities did not show significant differences among the two cultivars grown in the control conditions (Figure 3A,B). Under N fertilization, an increase in NR activity occurred only in Aureo (Figure 3A). In parallel with the ammonium content (Figure 2A), the GS activity was greater in the Vespucci roots than in the Aureo ones; however, fertilization stimulated the GS activity in both of the genotypes (Figure 3C). The NADH-GOGAT activity did not show a significant difference among the two durum cultivars without fertilization, and an increase occurred as a consequence of $\mathrm{N}$ supplementation (Figure 3D). 

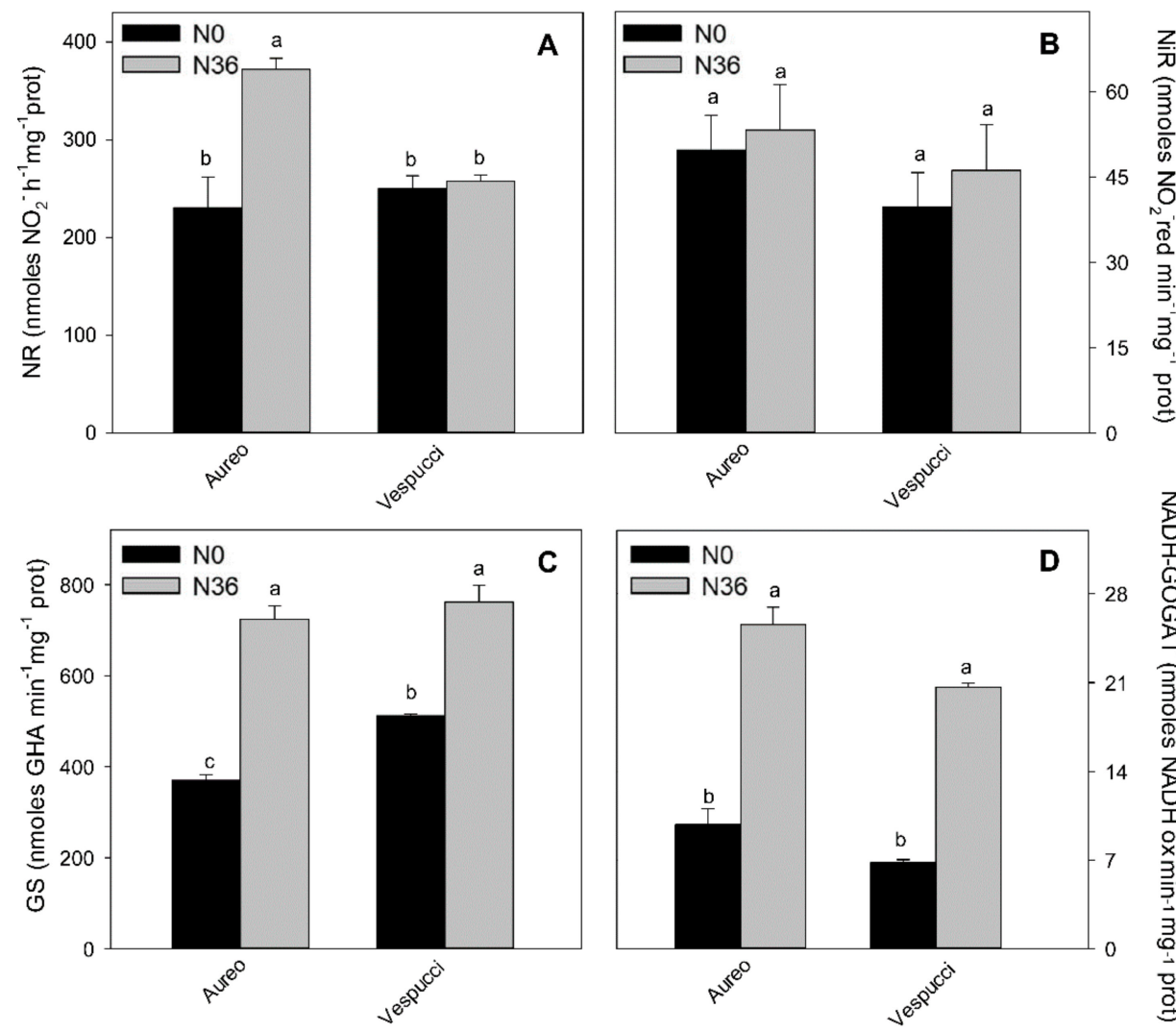

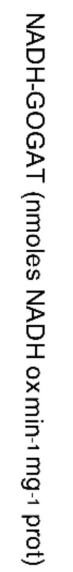

Figure 3. Influence of nitrogen fertilization on the enzymes of nitrogen metabolism in the roots of two wheat cultivars at the tillering stage. Specific activities of (A) nitrate reductase (NR), (B) nitrite reductase $(\mathrm{NiR}),(\mathbf{C})$ glutamine synthetase $(\mathrm{GS})$, and (D) glutamate synthase (NADH-GOGAT). N0 = control condition without nitrogen supply; $\mathrm{N} 36=36 \mathrm{U} /$ ha of nitrogen fertilization as ammonium nitrate. Data are the means \pm SE of five experiments; different letters indicate significant differences (one-way ANOVA test; $p<0.05)$.

The $\mathrm{N}$ content and metabolism has also been studied in the leaves of the two cultivars at the tillering stage (Figures 4 and 5). As observed in the roots, the intracellular ammonium content was higher in the Vespucci leaves than in Aureo's; the N supplement sharply reduced the content of this ion in both cultivars (Figure 4A). The nitrate content was comparable in the two cultivars grown without fertilization, and it increased approximately 100 times under ammonium nitrate treatment (Figure 4B). The nitrite content in the leaves was very low, and was not affected under fertilization in the two genotypes (data not shown). Despite the fact that in the control conditions, the amino acid pool was higher in Vespucci than in Aureo leaves, under $\mathrm{N}$ fertilization, this pool increased more in Aureo than in Vespucci (Figure 4C). Soluble proteins had comparable levels in the two cultivars grown in the absence of fertilization; $\mathrm{N}$ supplementation determined a significant increment, which did not show differences among the genotypes (Figure 4D). Chlorophylls, which represent another form of organic $\mathrm{N}$ storage, showed the same behavior of soluble proteins, increasing after $\mathrm{N}$ fertilization in the same way in both cultivars (Figure $4 \mathrm{E}, \mathrm{F}$ ). 

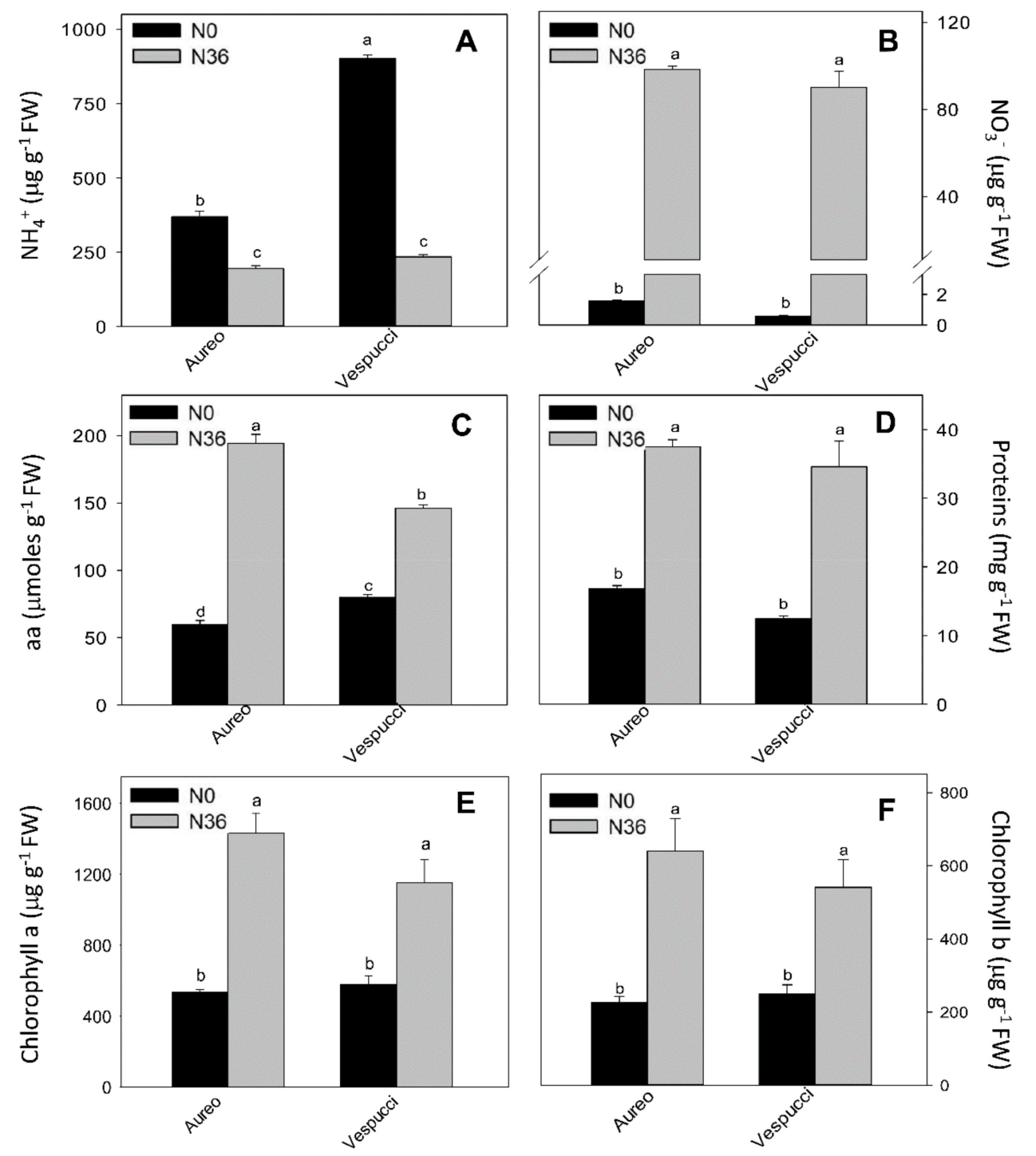

Figure 4. Effects of nitrogen fertilization on the nitrogen content in the leaves of two wheat cultivars at the tillering stage. Intracellular content of ammonium (A); nitrate (B), amino acids $(\mathbf{C})$, soluble proteins, (D), Chlorophyll A (E), and Chlorophyll B (F). N0 = control condition without nitrogen supply; N36 = $36 \mathrm{U} /$ ha of nitrogen fertilization as ammonium nitrate. Data are the means $\pm \mathrm{SE}$ of five experiments; different letters indicate significant differences (one-way ANOVA test; $p<0.05$ ).

The NR activity, which was not statistically different in the Vespucci and Aureo leaves under the control conditions, increased significantly with the $\mathrm{N}$ fertilization, reaching values significantly higher in Aureo than in Vespucci (Figure 5A).

The NiR activity was also induced by $\mathrm{N}$, and showed comparable values in both cultivars (Figure 5B). GS and Fd-GOGAT showed a similar activity in the leaves of both cultivars grown without fertilization (Figure 5C,D). When $\mathrm{N}$ was supplied, contrarily to what occurred in the roots, the GS activity significantly decreased in both genotypes (Figure 5C), and the Fd-GOGAT did not change in Aureo, and resulted in inhibition in Vespucci (Figure 5D). 

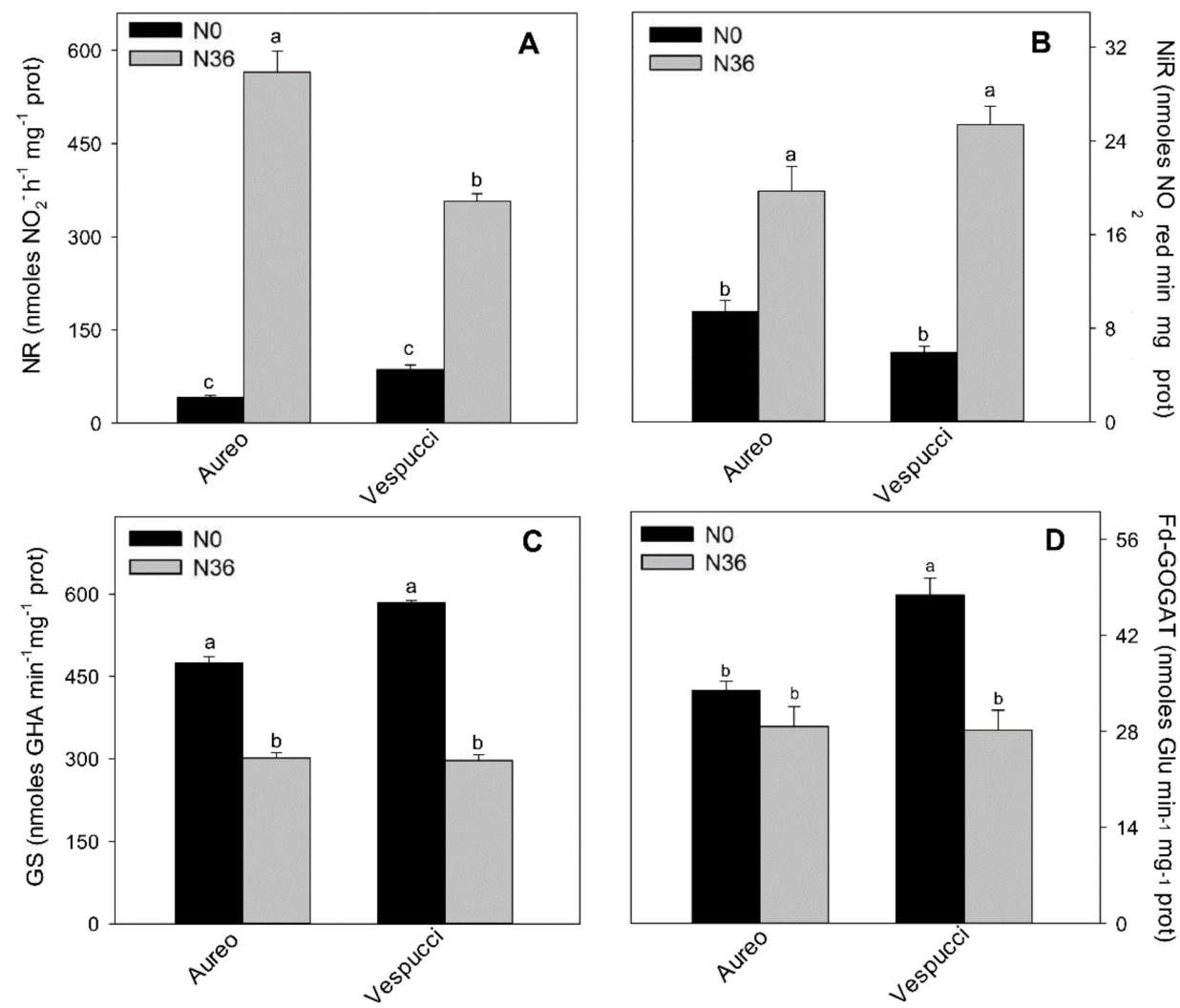

Figure 5. Influence of nitrogen fertilization on enzymes of nitrogen metabolism in the leaves of two wheat cultivars at the tillering stage. Specific activities of (A) nitrate reductase (NR), (B) nitrite reductase (NiR), (C) glutamine synthetase (GS), and (D) glutamate synthase (NADH-GOGAT). N0 = control condition without nitrogen supply; N36 = 36 U/ha of nitrogen fertilization as ammonium nitrate. Data are the means \pm SE of five experiments; different letters indicate significant differences (one-way ANOVA test; $p<0.05)$.

\section{Discussion}

$\mathrm{N}$ fertilization is one of the strategies more frequently used to increase crop yield [11]. Accordingly, our results show that after fertilization, $\mathrm{N}$ is absorbed and assimilated by both of the genotypes, as demonstrated by the increase in SPAD index in both the booting and flowering stages (Figure 1), which can be considered as an indirect measure of the $\mathrm{N}$ content of leaves [53-56]. The $\mathrm{N}$ availability for plants after fertilization is also deduced by the analyzed agronomic traits, such as the number of culms, number of spikes, and aerial biomass, which significantly increase in both genotypes (Table 1). In accordance with the literature data, the increase in aerial biomass can be due to an increase in the photosynthetic surface, and to a higher ability to produce reserve compounds, which results in a greater productivity, such as the number of grain $/ \mathrm{m}^{2}$ [57-60]. $\mathrm{N}$ fertilization increases all of the yield-related traits in both genotypes, but this increment is higher in Vespucci than in Aureo (Table 2). In wheat, $\mathrm{N}$ fertilization can also increase the $\mathrm{N}$ content of kernels, and consequently GPC [61], but this character shows a negative correlation with yield, whose extent is closely dependent on the genotype [62,63]. In Aureo, a simultaneous increase in both the yield and GPC occurs (Table 2), which highlights that this cultivar behaves as an optimal one, able to combine good yields with a high GPC [64,65]. The concomitant increase of yield and GPC in Aureo could be due to the efficient $\mathrm{N}$ translocation to the developing grains, as already suggested in previous papers [66,67], or to the different $\mathrm{N}$ uptake efficiency from the soil, probably attributed to its specific root architecture. It is known that wheat piles up most of its $\mathrm{N}$ before the booting and flowering stage. A good correlation between plant growth-related aspects during the early stages of the wheat vegetative cycle and final 
yield has been largely reported [68,69]. Furthermore, in bread wheat, $60-95 \%$ of the $\mathrm{N}$ in the grains is derived from the remobilization of $\mathrm{N}$ accumulated in the roots and shoots before anthesis $[37,70]$.

The exploitation of the genotype efficiencies in ammonium and nitrate use is of great importance to optimize not only NUE, but also grain quality. Our analyses on N metabolism, carried out during the tillering stage, show a complex metabolic scenario, which could be, in part, responsible of the differences in yield and GPC, occurring in the two wheat genotypes after inorganic $\mathrm{N}$ fertilization.

Without $\mathrm{N}$ fertilization, Vespucci's roots show a higher amount of intracellular ammonium, as well as of GS activity, than Aureo; after the N supply, a decrease in intracellular ammonium and a significant increase in amino acid pool and soluble proteins occur (Figure 2), suggesting that Vespucci's roots preferentially absorb and assimilate ammonium rather than nitrate. On the other hand, Aureo's roots have a higher nitrate content than Vespucci's; after the N supply, only Aureo's roots show an enhancement of NR activity (Figure 3). This different behavior of the two genotypes confirms that $\mathrm{N}$ absorption and assimilation are genotype specific [39,71,72].

In both genotypes, under control conditions, the NiR activity in the roots is significantly higher than the NR, and it does not increase after fertilization (Figure 3), confirming that this enzyme is not limiting. The high NiR activity makes sure that nitrite is quickly reduced to ammonium, to avoid its accumulation, which could be extremely harmful for cells [73]. Consistently, in both genotypes, nitrite is undetectable with or without $\mathrm{N}$ fertilization. At the same time, GS and GOGAT also behave similarly in the two cultivar's roots (Figure 3). The induction of these enzymes, observed in the roots grown under a high $\mathrm{N}$ availability is consistent with the previously published works, which show that ammonium specifically induces GS and NADH-GOGAT in the roots [2,74]. An increase in GS activity in the roots under ammonium nitrate fertilization, has been previously reported in other four different wheat genotypes [39]. The roots are the major site of primary ammonium assimilation, and GS and NADH-GOGAT activities are induced for ammonium assimilation and detoxification $[33,71,75]$.

In leaves, $\mathrm{N}$ metabolism shows some important differences between the two genotypes. As observed in the roots, in the leaves without fertilization, ammonium is higher in Vespucci than in Aureo; in this case, the N supply causes a drastic decrease of this ion in both genotypes (Figure 4). Thus, it is reasonable that, ammonium, being toxic even at a low concentration, is principally assimilated in the roots, and not transported to the leaves [76]. On the contrary, nitrate accumulation in leaves is higher than that observed in the roots (Figure 4), proving, in accordance with the literature, that a substantial portion of nitrate absorbed by the roots can be moved in the aerial part of plants [2]. The high nitrate concentration in the leaves induces a significant increase of NR and NiR activity in both genotypes, thus confirming that nitrate functions as an inducer of both enzymes [77,78].

Despite the inorganic N supplement that determined the increment of both NR and NiR activities and the reduction of ammonium levels, the GS activity was inhibited in both wheat genotypes, and the GOGAT activity does not change in Aureo and decreases in Vespucci (Figure 5). This is not surprising, because an inhibition of these enzymes was already observed previously in different wheat genotypes, with a high yield and GPC, growing with the high ammonium nitrate concentration [39,79]. The inhibition of the GS-GOGAT cycle can depend on the high nitrate concentration in leaves [79]. However, consistently with the high yield, the amino acids, proteins, and chlorophylls, which can give an estimation of total $\mathrm{N}$ [1], increase significantly after $\mathrm{N}$ fertilization in the leaves of both genotypes. It has been suggested that soluble proteins in vegetative organs make an exclusive pool of $\mathrm{N}$ accessible for the growth of vegetative and storage organs; the amplitude of this pool mirrors the plant $\mathrm{N}$ status [27,80-83].

The full genetic potential of $\mathrm{N}$ use is expected to be evident under non-limiting nitrogen supply [84], wherein Aureo and Vespucci differ significantly in their $\mathrm{N}$ metabolism. Indeed, although the amino acid content (Figure 4) and NR activity (Figure 5) after N fertilization rise in the leaves of both genotypes, the increase is significantly higher in Aureo than in Vespucci. These two parameters seem to be correlated, as it has been previously reported that the amino acid pool in the leaves could depend on the NR expression [85]. It has been shown that wheat genotypes with a high NR were able to 
mobilize a higher amount of $\mathrm{N}$ to the grains than the low NR genotypes [86]. Moreover, two wheat genotypes over-expressing a tobacco NR gene increased by $30 \%$ GPC, probably because the improved level of NR in the leaves accelerates nitrate assimilation and facilitate the $\mathrm{N}$ flux to the seeds during grain development [28]. Interestingly, also in different genotypes of pearl millet, a significant positive correlation among the NR activity at an early vegetative stage and GPC content of mature grains, has been demonstrated [87]. Consistently, our results support the hypothesis that the high induction of NR activity in Aureo after $\mathrm{N}$ fertilization could contribute to the increase in GPC. However, our data do not allow us to exclude that an increase in GPC, observed in Aureo after fertilization, can be also due to a high $\mathrm{N}$ mobilization, as well as to the plant's ability to utilize the $\mathrm{N}$ available in the soil during the ripening stage $[1,88,89]$.

\section{Conclusions}

Our results indicate that the two genotypes use the inorganic $\mathrm{N}$ exogenously supplied differently. Indeed, Aureo can increase both the yield and GPC after fertilization. The analyses of the N metabolism at the tillering stage in the two genotypes confirm that the $\mathrm{N}$ absorption and assimilation are genotype specific. Moreover, the increase in NR activity in the roots and leaves after $\mathrm{N}$ fertilization is significantly higher in Aureo than in Vespucci. These data could be taken into consideration in future works in order to check if the increase in NR activity under inorganic $\mathrm{N}$ fertilization could be used to choose the wheat genotypes able to increment both yield and GPC.

Supplementary Materials: The following are available online at http://www.mdpi.com/1424-2818/11/10/186/s1: Figure S1: Annual rainfall and average temperature data for the cropping season of 2016-2017 detected in the field trial of the University of Bari, Italy. Table S1: Particle size distribution, and chemical and hydrologic properties of the soil used in the trials.

Author Contributions: Conceptualization, S.F., D.N., A.B., A.G., G.C., and M.C.d.P.; methodology S.F., D.N., A.P., R.T., G.L., and G.A.; investigation, S.F., D.N., G.A., A.G., and M.C.d.P.; data analysis, S.F. and M.C.d.P.; writing (original draft preparation and review) and editing, S.F., D.N., A.G., and M.C.d.P.; supervision, A.G. and M.C.d.P. project administration, M.C.d.P.; funding acquisition, D.N. and A.G.

Funding: This research was funded by Project PON-ISCOCEM and “Intervento cofinanziato dal Fondo di Sviluppo e Coesione" 2007-2013-APQ Ricerca Regione Puglia Programma regionale a sostegno della specializzazione intelligente e della sostenibilità sociale ed ambientale-Future In Research".

Conflicts of Interest: The authors declare no conflict of interest.

\section{References}

1. Kichey, T.; Hirel, B.; Heumez, E.; Dubois, F.; Le Gouis, J. In winter wheat (Triticum aestivum L.), post-anthesis nitrogen uptake and remobilisation to the grain correlates with agronomic traits and nitrogen physiological markers. Field Crop. Res. 2007, 102, 22-32. [CrossRef]

2. Krapp, A. Plant nitrogen assimilation and its regulation: A complex puzzle with missing pieces. Curr. Opin. Plant Biol. 2015, 25, 115-122. [CrossRef] [PubMed]

3. Marschner, H. Marschner's Mineral Nutrition of Higher Plants, 3rd ed.; Academic Press: Cambridge, MA, USA, 2012.

4. Fois, N.; Schlichting, L.; Marchylo, B.; Dexter, J.; Motzo, R.; Giunta, F. Environmental conditions affect semolina quality in durum wheat (Triticum turgidum ssp. durum L.) cultivars with different gluten strength and gluten protein composition. J. Sci. Food Agric. 2011, 91, 2664-2673. [CrossRef] [PubMed]

5. Kaur, A.; Singh, N.; Kaur, S.; Katyal, M.; Virdi, A.S.; Kaur, D.; Singh, A.M. Relationship of various flour properties with noodle making characteristics among durum wheat varieties. Food Chem. 2015, 188, 517-526. [CrossRef] [PubMed]

6. Demotes-Mainard, S.; Jeuffroy, M.H. Partitioning of dry matter and nitrogen to the spike throughout the spike growth period in wheat crops subjected to nitrogen deficiency. Field Crop. Res. 2001, 70, $153-165$. [CrossRef]

7. Demotes-Mainard, S.; Jeuffroy, M.H. Incorporating radiation and nitrogen nutrition into a model of kernel number in wheat. Crop Sci. 2001, 41, 415-423. [CrossRef] 
8. Nigro, D.; Gadaleta, A.; Mangini, G.; Colasuonno, P.; Marcotuli, I.; Giancaspro, A.; Giove, S.L.; Simeone, R.; Blanco, A. Candidate genes and genome-wide association study of grain protein content and protein deviation in durum wheat. Planta 2019, 249, 1157-1175. [CrossRef]

9. Chope, G.A.; Wan, Y.; Penson, S.P.; Bhandari, D.G.; Powers, S.J.; Shewry, P.R.; Hawkesford, M.J. Effects of genotype, season, and nitrogen nutrition on gene expression and protein accumulation in wheat grain. $J$. Agric. Food Chem. 2014, 62, 4399-4407. [CrossRef]

10. Maccaferri, M.; Harris, N.S.; Twardziok, S.O.; Pasam, R.K.; Gundlach, H.; Spannagl, M.; Ormanbekova, D.; Lux, T.; Prade, V.M.; Milner, S.G.; et al. Durum wheat genome highlights past domestication signatures and future improvement targets. Nat. Genet. 2019, 51, 885-895. [CrossRef]

11. Laidig, F.; Piepho, H.P.; Rentel, D.; Drobek, T.; Meyer, U.; Huesken, A. Breeding progress, environmental variation and correlation of winter wheat yield and quality traits in German official variety trials and on-farm during 1983-2014. Theor. Appl. Genet. 2017, 130, 223-245. [CrossRef]

12. Garnett, T.; Conn, V.; Kaiser, B.N. Root based approaches to improving nitrogen use efficiency in plants. Plant Cell Environ. 2009, 32, 1272-1283. [CrossRef] [PubMed]

13. Garrido-Lestache, E.; López-Bellido, R.J.; López-Bellido, L. Durum wheat quality under Mediterranean conditions as affected by $\mathrm{N}$ rate, timing and splitting, $\mathrm{N}$ form and $\mathrm{S}$ fertilization. Eur. J. Agron. 2005, 23, 265-278. [CrossRef]

14. Fuertes-Mendizábal, T.; Aizpurua, A.; González-Moro, M.B.; Estavillo, J.M. Improving wheat breadmaking quality by splitting the $\mathrm{N}$ fertilizer rate. Eur. J. Agron. 2010, 33, 52-61. [CrossRef]

15. Ercoli, L.; Arduini, I.; Mariotti, M.; Lulli, L.; Masoni, A. Management of sulphur fertiliser to improve durum wheat production and minimise S leaching. Eur. J. Agron. 2012, 38, 74-82.

16. Moll, R.H.; Kamprath, E.J.; Jackson, W.A. Development of nitrogen efficient prolific hybrids of maize. Crop Sci. 1987, 27, 181-186. [CrossRef]

17. Le Gouis, J.; Beghin, D.; Heumez, E.; Pluchard, P. Genetic differences for nitrogen uptake and nitrogen utilisation efficiencies in winter wheat. Eur. J. Agron. 2000, 12, 163-173. [CrossRef]

18. Dawson, J.C.; Huggins, D.R.; Jones, S.S. Characterizing nitrogen use efficiency in natural and agricultural ecosystems to improve the performance of cereal crops in low-input and organic agricultural systems. Field Crop. Res. 2008, 107, 89-101. [CrossRef]

19. Giambalvo, D.; Ruisi, P.; Di Miceli, G.; Frenda, A.S.; Amato, G. Nitrogen Use Efficiency and Nitrogen Fertilizer Recovery of Durum Wheat Genotypes as Affected by Interspecific Competition. Agron. J. 2010, 102, 707-715. [CrossRef]

20. Cossani, C.M.; Slafer, G.A.; Savin, R. Nitrogen and water use efficiencies of wheat and barley under a Mediterranean environment in Catalonia. Field Crop. Res. 2012, 128, 109-118. [CrossRef]

21. Lopez-Bellido, L.; Lopez-Bellido, R.J.; Lopez-Bellido, F.J. Fertilizer nitrogen efficiency in durum wheat under rainfed Mediterranean conditions: Effect of split application. Agron. J. 2006, 98, 55-62. [CrossRef]

22. Andrews, M.; Morton, J.D.; Lieffering, M.; Bisset, L. The partitioning of nitrate assimilation between root and shoot of a range of temperate cereals and pasture grasses. Ann. Bot. Lond. 1992, 70, 271-276. [CrossRef]

23. Lillo, C. Signalling cascades integrating light-enhanced nitrate metabolism. Biochem. J. 2008, 415, 11-19. [CrossRef] [PubMed]

24. Heidari, B.; Matre, P.; Nemie-Feyissa, D.; Meyer, C.; Rognli, O.A.; Moller, S.G.; Lillo, C. Protein phosphatase 2A B55 and A regulatory subunits interact with nitrate reductase and are essential for nitrate reductase activation. Plant Physiol. 2011, 156, 165-172. [CrossRef] [PubMed]

25. Blackwood, G.C.; Hallam, R. Nitrate reductase activity in wheat (Triticum aestivum L.) II. The correlation with yield. New Phytol. 1979, 82, 417-425. [CrossRef]

26. Srivastava, H.S. Regulation of nitrate reductase activity in higher plants. Phytochemistry 1980, 19, 725-733. [CrossRef]

27. Kumari, S. Yield response of uniculm wheat (Triticum aestivum L.) to early and late application of nitrogen: Flag leaf development and senescence. J. Agric. Sci. 2011, 3, 170-182. [CrossRef]

28. Zhao, X.Q.; Nie, X.L.; Xiao, X.G. Over-Expression of a tobacco nitrate reductase gene in wheat (Triticum aestivum $\mathrm{L}$.) increases seed protein content and weight without augmenting nitrogen supplying. PLoS ONE 2013, 8, e74678. [CrossRef] [PubMed] 
29. Esposito, S.; Guerriero, G.; Vona, V.; Rigano, V.D.; Carfagna, S.; Rigano, C. Glutamate synthase activities and protein changes in relation to nitrogen nutrition in barley: The dependence on different plastidic glucose-6P dehydrogenase isoforms. J. Exp. Bot. 2005, 56, 55-64. [CrossRef]

30. Wang, R.C.; Tischner, R.; Gutierrez, R.A.; Hoffman, M.; Xing, X.J.; Chen, M.S.; Coruzzi, G.; Crawford, N.M. Genomic analysis of the nitrate response using a nitrate reductase-null mutant of Arabidopsis. Plant Physiol. 2004, 136, 2512-2522. [CrossRef] [PubMed]

31. Zhou, W.; Sun, Q.J.; Mang, C.F.; Yuan, Y.Z.; Ji, Z.; Lu, B.B. Effect of salt stress on ammonium assimilation enzymes of the roots of rice (Oryza sativa) genotypes differing in salinity resistance. Acta Bot. Sin. 2004, 46, 921-927.

32. Raymond, J. The evolution of biological carbon and nitrogen cycling-A genomic perspective. Rev. Miner. Geochem. 2005, 59, 211-231. [CrossRef]

33. Tabuchi, M.; Abiko, T.; Yamaya, T. Assimilation of ammonium ions and reutilization of nitrogen in rice (Oryza sativa L.). J. Exp. Bot. 2007, 58, 2319-2327. [CrossRef] [PubMed]

34. Canovas, F.M.; Avila, C.; Canton, F.R.; Canas, R.A.; de la Torre, F. Ammonium assimilation and amino acid metabolism in conifers. J. Exp. Bot. 2007, 58, 2307-2318. [CrossRef]

35. Nigro, D.; Gu, Y.Q.; Huo, N.X.; Marcotuli, I.; Blanco, A.; Gadaleta, A.; Anderson, O.D. Structural analysis of the wheat genes encoding NADH-dependent glutamine-2-oxoglutarate amidotransferases and correlation with grain protein content. PLoS ONE 2013, 8, e73751. [CrossRef] [PubMed]

36. Nigro, D.; Blanco, A.; Anderson, O.D.; Gadaleta, A. Characterization of ferredoxin-dependent glutamine-oxoglutarate amidotransferase (Fd-GOGAT) genes and their relationship with grain protein content QTL in wheat. PLoS ONE 2014, 9, e103869. [CrossRef]

37. Habash, D.Z.; Bernard, S.; Schondelmaier, J.; Weyen, J.; Quarrie, S.A. The genetics of nitrogen use in hexaploid wheat: N utilisation, development and yield. Theor. Appl. Genet. 2007, 114, 403-419. [CrossRef] [PubMed]

38. Thomsen, H.C.; Eriksson, D.; Moller, I.S.; Schjoerring, J.K. Cytosolic glutamine synthetase: A target for improvement of crop nitrogen use efficiency? Trends Plant Sci. 2014, 19, 656-663. [CrossRef]

39. Nigro, D.; Fortunato, S.; Giove, S.L.; Paradiso, A.; Gu, Y.Q.; Blanco, A.; de Pinto, M.C.; Gadaleta, A. Glutamine synthetase in durum wheat: Genotypic variation and relationship with grain protein content. Front. Plant Sci. 2016, 7, 971. [CrossRef]

40. Nigro, D.; Fortunato, S.; Giove, S.L.; Mangini, G.; Yacoubi, I.; Simeone, R.; Blanco, A.; Gadaleta, A. Allelic variants of glutamine synthetase and glutamate synthase genes in a collection of durum wheat and association with grain protein content. Divers. Basel 2017, 9, 52. [CrossRef]

41. Gadaleta, A.; Nigro, D.; Marcotuli, I.; Giancaspro, A.; Giove, S.L.; Blanco, A. Isolation and characterization of cytosolic glutamine synthetase (GSe) genes and association with grain protein content in durum wheat. Crop Pasture Sci. 2014, 65, 38-45. [CrossRef]

42. Quaranta, F.; Belocchi, A.; Fornara, M.; Mazzon, V.; Cecchini, C.; Nocente, F. Le varietà di grano duro per le semine 2015. L'informatore Agrario. 2015, 33, 5-11. (In Italian)

43. Quaranta, F.; Belocchi, A.; Cecchini, C.; Mazzon, V.; Fornara, M. Le varietà di grano duro per le semine 2016. L'informatore Agrario. 2016, 33, 25-31. (In Italian)

44. Violante, P. Methods of Soil Chemical Analyses; Franco Angeli: Milano, Italy, 2000.

45. Varga, B.; Svecnjak, Z. The effect of late-season urea spraying on grain yield and quality of winter wheat genotypes under low and high basal nitrogen fertilization. Field Crop. Res. 2006, 96, 125-132. [CrossRef]

46. Verdon, C.P.; Burton, B.A.; Prior, R.L. Sample pretreatment with nitrate reductase and glucose-6-phosphate-dehydrogenase quantitatively reduces nitrate while avoiding interference by NADP+ when the Griess reaction is used to assay for nitrite. Anal. Biochem. 1995, 224, 502-508. [CrossRef] [PubMed]

47. Magné, C.; Larher, F. High sugar content of extracts interferes with colorimetric determination of amino-acids and free proline. Anal. Biochem. 1992, 200,115-118. [CrossRef]

48. Bradford, M.M. A rapid and sensitive method for the quantitation of microgram quantities of protein utilizing the principle of protein-dye binding. Anal. Biochem. 1976, 72, 248-254. [CrossRef] 
49. Zhang, J.X.; Kirkham, M.B. Antioxidant responses to drought in sunflower and sorghum seedlings. New Phytol. 1996, 132, 361-373. [CrossRef] [PubMed]

50. Gibon, Y.; Blaesing, O.E.; Hannemann, J.; Carillo, P.; Hohne, M.; Hendriks, J.H.M.; Palacios, N.; Cross, J.; Selbig, J.; Stitt, M. A robot-based platform to measure multiple enzyme activities in Arabidopsis using a set of cycling assays: Comparison of changes of enzyme activities and transcript levels during diurnal cycles and in prolonged darkness. Plant Cell 2004, 16, 3304-3325. [CrossRef]

51. Takahashi, M.; Sasaki, Y.; Ida, S.; Morikawa, H. Nitrite reductase gene enrichment improves assimilation of NO(2) in Arabidopsis. Plant Physiol. 2001, 126, 731-741. [CrossRef]

52. Esposito, S.; Guerriero, G.; Vona, V.; Rigano, V.D.M.; Carfagna, S.; Rigano, C. Glucose-6P dehydrogenase in Chlorella sorokiniana (211/8k): An enzyme with unusual characteristics. Planta 2006, 223, 796-804. [CrossRef]

53. Follett, R.H.; Follett, R.F.; Halvorson, A.D. Use of a Chlorophyll Meter to evaluate the nitrogen status of dryland winter-wheat. Commun. Soil Sci. Plant 1992, 23, 687-697. [CrossRef]

54. Cartelat, A.; Cerovic, Z.G.; Goulas, Y.; Meyer, S.; Lelarge, C.; Prioul, J.L.; Barbottin, A.; Jeuffroy, M.H.; Gate, P.; Agati, G.; et al. Optically assessed contents of leaf polyphenolics and chlorophyll as indicators of nitrogen deficiency in wheat (Triticum aestivum L.). Field Crop. Res. 2005, 91, 35-49. [CrossRef]

55. Debaeke, P.; Rouet, P.; Justes, E. Relationship between the normalized SPAD index and the nitrogen nutrition index: Application to durum wheat. J. Plant Nutr. 2006, 29, 75-92. [CrossRef]

56. Xiong, D.L.; Chen, J.; Yu, T.T.; Gao, W.L.; Ling, X.X.; Li, Y.; Peng, S.B.; Huang, J.L. SPAD-based leaf nitrogen estimation is impacted by environmental factors and crop leaf characteristics. Sci. Rep. UK 2015, 5, 13389. [CrossRef] [PubMed]

57. Nielsen, D.C.; Halvorson, A.D. Nitrogen fertility influence on water-stress and yield of winter-wheat. Agron. J. 1991, 83, 1065-1070. [CrossRef]

58. Spano, G.; Di Fonzo, N.; Perrotta, C.; Platani, C.; Ronga, G.; Lawlor, D.W.; Napier, J.A.; Shewry, P.R. Physiological characterization of 'stay green' mutants in durum wheat. J. Exp. Bot. 2003, 54, 1415-1420. [CrossRef]

59. Masclaux-Daubresse, C.; Reisdorf-Cren, M.; Orsel, M. Leaf nitrogen remobilisation for plant development and grain filling. Plant Biol. 2008, 10, 23-36. [CrossRef]

60. Zhang, F.F.; Gao, S.; Zhao, Y.Y.; Zhao, X.L.; Liu, X.M.; Xiao, K. Growth traits and nitrogen assimilation-associated physiological parameters of wheat (Triticum aestivum L.) under low and high N conditions. J. Integr. Agr. 2015, 14, 1295-1308. [CrossRef]

61. Giuliani, M.M.; Giuzio, L.; De Caro, A.; Flagella, Z. Relationships between nitrogen utilization and grain technological quality in durum wheat: II. Grain yield and quality. Agron. J. 2011, 103, 1668-1675. [CrossRef]

62. Blanco, A.; Pasqualone, A.; Troccoli, A.; Di Fonzo, N.; Simeone, R. Detection of grain protein content QTLs across environments in tetraploid wheats. Plant Mol. Biol. 2002, 48, 615-623. [CrossRef]

63. Oury, F.X.; Godin, C. Yield and grain protein concentration in bread wheat: How to use the negative relationship between the two characters to identify favourable genotypes? Euphytica 2007, 157, 45-57. [CrossRef]

64. Cox, M.C.; Qualset, C.O.; Rains, D.W. Genetic-variation for nitrogen assimilation and translocation in wheat. 2. nitrogen assimilation in relation to grain-yield and protein. Crop Sci. 1985, 25, 435-440. [CrossRef]

65. Monaghan, J.M.; Snape, J.W.; Chojecki, A.J.S.; Kettlewell, P.S. The use of grain protein deviation for identifying wheat cultivars with high grain protein concentration and yield. Euphytica 2001, 122, 309-317. [CrossRef]

66. Garrido-Lestache, E.; Lopez-Bellido, R.J.; Lopez-Bellido, L. Effect of N rate, timing and splitting and N type on bread-making quality in hard red spring wheat under rainfed Mediterranean conditions. Field Crop. Res. 2004, 85, 213-236. [CrossRef]

67. Galieni, A.; Stagnari, F.; Visioli, G.; Marmiroli, N.; Speca, S.; Angelozzi, G.; D’Egidio, S.; Pisante, M. Nitrogen fertilisation of durum wheat: A case study in Mediterranean area during transition to conservation agriculture. Ital. J. Agron. 2016, 11, 12-23. [CrossRef]

68. Slafer, G.A. Genetic basis of yield as viewed from a crop physiologist's perspective. Ann. Appl. Biol. 2003, 142, 117-128. [CrossRef]

69. Marti, J.; Bort, J.; Slafer, G.A.; Araus, J.L. Can wheat yield be assessed by early measurements of Normalized Difference Vegetation Index? Ann. Appl. Biol. 2007, 150, 253-257. [CrossRef]

70. Palta, J.A.; Fillery, I.R.P. N application increases pre-anthesis contribution of dry matter to grain yield in wheat grown on a duplex soil. Aust. J. Agric. Res. 1995, 46, 507-518. [CrossRef] 
71. Masclaux-Daubresse, C.; Daniel-Vedele, F.; Dechorgnat, J.; Chardon, F.; Gaufichon, L.; Suzuki, A. Nitrogen uptake, assimilation and remobilization in plants: Challenges for sustainable and productive agriculture. Ann. Bot. Lond. 2010, 105, 1141-1157. [CrossRef] [PubMed]

72. Kaur, G.; Asthir, B.; Bains, N.S.; Farooq, M. Nitrogen nutrition, its assimilation and remobilization in diverse wheat genotypes. Int. J. Agric. Biol. 2015, 17, 531-538. [CrossRef]

73. Foyer, C.H.; Noctor, G. Photosynthetic nitrogen assimilation: Inter-pathway control and signalling. In Photosyntetic Nitrogen Assimilation and Associated Carbon and Respiratory Metabolism; Foyer, C.H., Noctor, G., Eds.; Kluwer: Amsterdam, The Netherlands, 2002; pp. 1-22.

74. Andrews, M.; Raven, J.A.; Lea, P.J. Do plants need nitrate? The mechanisms by which nitrogen form affects plants. Ann. Appl. Biol. 2013, 163, 174-199. [CrossRef]

75. Lothier, J.; Gaufichon, L.; Sormani, R.; Lemaitre, T.; Azzopardi, M.; Morin, H.; Chardon, F.; Reisdorf-Cren, M.; Avice, J.C.; Masclaux-Daubresse, C. The cytosolic glutamine synthetase GLN1;2 plays a role in the control of plant growth and ammonium homeostasis in Arabidopsis rosettes when nitrate supply is not limiting. J. Exp. Bot. 2011, 62, 1375-1390. [CrossRef] [PubMed]

76. Hachiya, T.; Watanabe, C.K.; Fujimoto, M.; Ishikawa, T.; Takahara, K.; Kawai-Yamada, M.; Uchimiya, H.; Uesono, Y.; Terashima, I.; Noguchi, K. Nitrate addition alleviates ammonium toxicity without lessening ammonium accumulation, organic acid depletion and inorganic cation depletion in Arabidopsis thaliana shoots. Plant Cell Physiol. 2012, 53, 577-591. [CrossRef] [PubMed]

77. Oaks, A. Primary nitrogen assimilation in higher-plants and its regulation. Can. J. Bot. 1994, 72, 739-750. [CrossRef]

78. Campbell, W.H. Nitrate reductase structure, function and regulation: Bridging the gap between biochemistry and physiology. Ann. Rev. Plant. Physiol. Plant Mol. Biol. 1999, 50, 277-303. [CrossRef] [PubMed]

79. Balotf, S.; Kavoosi, G.; Kholdebarin, B. Nitrate reductase, nitrite reductase, glutamine synthetase, and glutamate synthase expression and activity in response to different nitrogen sources in nitrogen-starved wheat seedlings. Biotechnol. Appl. Biochem. 2016, 63, 220-229. [CrossRef]

80. Makino, A.; Mae, T.; Ohira, K. Photosynthesis and ribulose-1,5-bisphosphate carboxylase oxygenase in rice leaves from emergence through senescence-quantitative-analysis by carboxylation oxygenation and regeneration of ribulose 1,5-bisphosphate. Planta 1985, 166, 414-420. [CrossRef] [PubMed]

81. Hageman, J.; Robinson, C.; Smeekens, S.; Weisbeek, P. A Thylakoid Processing Protease Is Required for Complete Maturation of the Lumen Protein Plastocyanin. Nature 1986, 324, 567-569. [CrossRef]

82. Lawlor, D.W.; Kontturi, M.; Young, A.T. Photosynthesis by flag leaves of wheat in relation to protein, ribulose bisphosphate carboxylase activity and nitrogen supply. J. Exp. Bot. 1989, 40, 43-52. [CrossRef]

83. Thornley, J.H.M. Acclimation of photosynthesis to light and canopy nitrogen distribution: An interpretation. Ann. Bot. Lond. 2004, 93, 473-475. [CrossRef]

84. Anjana, S.U.; Umar, S.; Abrol, Y.P.; Iqbal, M. Modulation of Nitrogen-Utilization Efficiency in Wheat Genotypes Differing in Nitrate Reductase Activity. J. Plant Nutr. 2011, 34, 920-933. [CrossRef]

85. Scheible, W.R.; GonzalezFontes, A.; Lauerer, M.; MullerRober, B.; Caboche, M.; Stitt, M. Nitrate acts as a signal to induce organic acid metabolism and repress starch metabolism in tobacco. Plant Cell 1997, 9, 783-798. [CrossRef] [PubMed]

86. Jain, V.; Khetarpal, S.; Das, R.; Abrol, Y.P. Nitrate assimilation in contrasting wheat genotypes. Physiol. Mol. Biol. Plants 2011, 17, 137-144. [CrossRef] [PubMed]

87. Berwal, M.K.; Chugh, L.K.; Kumar, R. Possibility of using leaf in vivo nitrate reductase activity as a biochemical marker for predicting grain protein content of pearl millet. Int. J. Curr. Microbiol. Appl. Sci. 2015, 4, 630-634.

88. Bertin, P.; Gallais, A. Genetic variation for nitrogen use efficiency in a set of recombinant maize inbred lines I. Agrophysiological results. Maydica 2000, 45, 53-66.

89. Gallais, A.; Coque, M. Genetic Variation and Selection for Nitrogen Use Efficiency in Maize: A Synthesis. Maydica 2005, 50, 531-547.

(C) 2019 by the authors. Licensee MDPI, Basel, Switzerland. This article is an open access article distributed under the terms and conditions of the Creative Commons Attribution (CC BY) license (http://creativecommons.org/licenses/by/4.0/). 